\title{
Validation of a Diagnostic Protocol for the Detection of Fusarium oxysporum f.sp. albedinis, the Causal Agent of Bayoud Disease of Date Palm
}

\author{
Ahmed, Y. ${ }^{1}$; Hussien, A. ${ }^{2,3}$; El-badry, N. $^{2}$ and \\ Soliman, M.S. ${ }^{1}$ \\ 1- Plant Quarantine Pathogens Laboratory, Mycology \\ Research \& Disease Survey, Plant Pathology Research \\ Institute, Agricultural Research Center, Giza, Egypt. \\ 2- Central Administration of Plant Quarantine, Ministry of \\ Agriculture and Land Reclamation, Giza 12618, Egypt \\ 3- Regional Office for Near East and North Africa, Food and \\ Agriculture Organization of the United Nations, Giza, \\ Egypt
}

\begin{abstract}
The recommended EPPO diagnostic protocol for detection and 1 identification of Fusarium oxysporum f.sp. albedinis (FOA), the causal agent of Bayoud disease of date palm (Phoenix dactylifera) was validated under Egyptian laboratory conditions. The validation process was carried out in The Plant Quarantine Pathogens Laboratory (PQPL), Plant Pathology Research Institute, Agricultural Research Center (ARC). The performance criteria were assessed for the conventional PCR methods and recommend by EPPO as PM 7/16(1) (2002, 2009). The sensitivity, specificity, repeatability, and reproducibility of the method were tested for different concentrations of pure culture of FOA. The method was proved to be unambiguously specific to detect FOA. The limit of detection (LOD) of the method was $1 \mathrm{ng} \mu \mathrm{l}^{-1}$ and $100 \%$ reproducibility and repeatability were also achieved. Moreover, the validated method was then implemented for testing date palm samples presenting lots of imported planting materials (43 samples) from different origins in addition to different samples collected from domestic plantations (14 samples) presenting different locations in Egypt. Although $F$. oxysporum was isolated from most of the tested samples but the presence of FOA in all samples was nil.
\end{abstract}

Keywords: Bayoud; date palm; Fusarium oxysporum f.sp. albedinis, molecular detection, $\mathrm{PCR}$, specific primers.

Date palm (Phoenix dactylifera) is one of the oldest fruit trees domesticated by human worldwide. Egypt is a major date producing country and ranked the top producer in terms of quantity and the number of cultivated date-palm trees. In 2018 the Egyptian production of dates exceeded 11 million tons (FAOSTAT, 2018). Date palm is considered an important component of the farming systems in dry and semiarid regions, particularly in oasis agroecosystem. 
Fusarium wilt of date palm or "Bayoud" is the most dangerous disease resulting in significant losses annually. The disease is caused by Fusarium oxysporum f.sp. albedinis (FOA) and considered as the most serious pathogenic fungus threatening date palm in North Africa, especially in Morocco where it has been reported since 1870 (Djerbi, 1982). The fungus may result in killing the trees within few months up to two years after infection. Bayoud has killed more than twelve million palm trees in Morocco (Djerbi, 1983; Fernandez et al., 1995), and more than three million in Algeria (Benzohra et al., 2017). In Morocco, the disease continues to cause complete decline of 4.5-12\% of date palms per year (Djerbi 1983). Most of varieties of high quality and yield are susceptible to Bayoud (Benzohra et al., 2017). In Mauritania, Fusarium wilt led to the loss of many productive varieties especially the spontaneous seedling date palm resulting in the depletion of the date palm gene pool in different regions and the deterioration of oases (Sedra, 2015). Furthermore, this disease has greatly contributed in accelerating the desertification phenomenon by aboloshing the green coverage sheltered in date-palm grooves, and many farmers abandoned their land and moved to urban centres (Toutain and Louvet, 1974). Primarily, Fusarium infection occurs through the roots and spreads internally through the vascular system of the host plant. Dispersal of the pathogen occurs by means of infected offshoots, soil, other symptomless hosts, infected date tissues and irrigation water. Although $F$. oxysporum f.sp. albedinis is currently present in Morocco, Algeria and Mauritania, it has not yet been reported in Egypt and therefore it is regulated in the A1 Egyptian quarantine list based on the Egyptian Plant Quarantine legislation (Decree No. 562/2019). However, the fungus could potentially enter Egypt on host plants and soil/growing media imported from infested countries. It is worth mentioning that once this pathogen enters Egypt, it could easily establish and spread due to the suitable climate and the abundance of susceptible varieties. The introduction of a quarantine fungus will have several impacts and negative consequences on date production in Egypt.

The likelihood of fungus entry could be mitigated if proper phytosanitary measures are strictly enforced. Among the necessary measures, limiting importation of plant materials and soil/growing media to be only from Bayoud-free areas. More importantly, the imported materials must be thoroughly inspected, and laboratory tested against $F$. oxysporum $\mathrm{f}$. sp. albedinis, both at the place of origin and at the entry point in Egypt. The availability of reliable detection methods for quarantine pathogens in diagnostic laboratories is crucial for phytosanitary measures. It is essential that any diagnostic protocol intends for routine diagnosis should meet the minimum requirements of reliability and quality control, including fulfilling the key performance criteria. As European Union (EU) and member states of the European and Mediterranean Plant Protection Organization (EPPO) are the main trade partners for Egypt, it is recommended to apply harmonised diagnostic protocols that are validated and fulfilling the requirements of EPPO standard PM 7/98 (EPPO, 2010). The validation process aims to ensure that the performance criteria of the method

Egypt. J. Phytopathol., Vol. 47, No. 1 (2019) 
can satisfy the desired reliability and accuracy and allow the laboratories to provide objective evidence that they can operate the test according to the international standards. Testing the specificity is the main component in any validation process which proves the ability of the test to exclude true negatives (cross-reactions with non-target) e.g. false positives. Analytical sensitivity is the least amount of target pathogen that can be detected reliably by the test. Repeatability is the ability of the test to provide full agreement between replicates of the same sample tested under the same conditions. While the reproducibility is the ability of the test to provide consistent results when testing the same sample under different conditions (personnel, equipment, and time). In this study, we aimed to 1) validate an accurate and reliable diagnostic method for detection of $F$. oxysporum f.sp. albedinis; 2) investigate the performance criteria data of this method; and 3) implement this diagnostic method in testing date palm samples either from Egyptian plantings or imported date palm plantlets.

\section{Materials and Methods}

\section{Fungal isolates, culturing conditions and DNA extraction:}

Different fungal isolates of F. oxysporum and other Fusarium species were used in this study (Table 1). These isolates were obtained from the culture collection of the Mycology Res. and Disease Survey Dept., Plant Pathol. Res. Inst., ARC, Egypt. In addition, $F$. oxysporum f.sp. albedinis (LSVM302), the positive reference (Nonpathogenic, mutant strain) used in this investigation, was obtained from the culture collection of the Mycology Unit of the French Agency for Food, Environmental and Occupational Health \& Safety/ANSES according to an official approval issued by the Agricultural Research Centre (ARC) and Central Administration of Plant Quarantine (CAPQ). ANSES laboratory is the European Reference Laboratory (ERL) that conducts research on the development of reference analytical methods for detecting and identifying quarantine pathogens.

Our investigation was entirely carried out at the PQPL lab. which is one of the accredited labs of the Plant Pathol. Res. Inst, ARC. PQPL is accredited according to the requirements of ISO/IEC 17025:2017 (2017) quality system. Therefore, the access to the lab area and the handling of the reference strains are highly restricted to authorized and competent personnel.

All the isolates were grown on potato dextrose agar (PDA) plates and incubated at $27 \pm 1^{\circ} \mathrm{C}$ for 10 to 15 days. Mycelial growth was harvested from the surface of the fungal culture plates then grinded in liquid nitrogen using a mortar and pestle under sterilised conditions. Genomic DNA (gDNA) was extracted using DNeasy Plant Mini Kit (QIAGEN) following the manufacturer instructions. The concentrations of the extracted DNA were measured using a ND-1000 spectrophotometer (Nano Drop Technologies) then the DNA extracts were stored at $-20^{\circ} \mathrm{C}$ till used. In order to confirm the identity of all the fungal isolates used in this investigation and to check 
the amplifiability of the extracted DNA, a PCR analysis was carried out for sequencing the internal transcribed spacer region using the ITS1/ITS4 primer pair (White et al., 1990).

Validation of the molecular detection method of F. oxysporum f.sp. albedinis:

Selection of the method:

The molecular conventional PCR method developed by Fernandez et al. (1998) was selected in this study for the validation process. This method was recommended by EPPO and was drafted as diagnostic protocol PM 7/16(1) (2002 and 2009) since it has proved to unambiguously differentiate $F$. oxysporum f.sp. albedinis from other $F$. oxysporum formae specials or any other fungal species.

\section{Preliminary evaluation and checking the PCR conditions:}

An initial PCR was carried out using the DNA template of the referent isolate $F$. oxysporum f.sp. albedinis (LSVM 302) and DNA of F. oxysporum f.sp. lycopersici (PQPL-95-5) in order to check the PCR conditions of the method that will be adopted in this investigation.

The primer pair of TL3 (5'-GGTCGTCCGCAGAGTATACCGGC-3') and FOA28 (5'-ATCCCCGTAAAGCCCTGAAGC-3') designed by Fernandez et al. (1998) was used to amplify a fragment of $400 \mathrm{bp}$. The conventional PCR was performed in $25 \mu \mathrm{l}$ reaction volume containing $1.25 \mu \mathrm{l}$ of Taq buffer 10X (Biomatik, Ontario, Canada), $1.5 \mathrm{mM}$ of $\mathrm{MgCl}_{2}, 100 \mu \mathrm{M}$ of each dNTP, $0.5 \mu \mathrm{M}$ of each primer, $0.25 \mathrm{U}$ Taq DNA polymerase (Biomatik, Ontario, Canada), $2 \mu \mathrm{l}$ of template DNA, and the reaction mixture was then adjusted to $25 \mu \mathrm{l}$ by molecular grade water. PCR was performed in thermocycler (Applied Biosystems, Foster City, CA) and the cycling program was as follows: an initial denaturation step at $95^{\circ} \mathrm{C}$ for $4 \mathrm{~min}$, then 30 cycles of denaturation at $92^{\circ} \mathrm{C}$ for $30 \mathrm{sec}$, annealing at $62^{\circ} \mathrm{C}$ for $30 \mathrm{sec}$ and elongation at $72^{\circ} \mathrm{C}$ for $45 \mathrm{sec}$ then a final extension step for $15 \mathrm{~min}$ at $72^{\circ} \mathrm{C}$. PCR amplicons were separated by electrophoresis in $1 \%$ agarose gels in TAE buffer that contained gel stain of EZView (Biomatik, Ontario, Canada) and analysed under UV light. The results were inferred qualitatively and the isolate yielded amplicons of $400 \mathrm{bp}$ was designated as $F$. oxysporum f.sp. albedinis.

Performance criteria of the conventional PCR assay:

Testing the conventional PCR specificity:

The specificity of the conventional PCR assay was performed to verify the ability of the test to exclude cross-reaction with DNA of non-target species (false positives). The assessment included six isolates representing three formae specialis that were collected from tomato, pepper and watermelon, in addition to, two $F$. oxysporum isolates, one $F$. solani isolate and two isolates of Fusarium species isolated from date palm (Table 1). The gDNA was normalized to a concentration of

Egypt. J. Phytopathol., Vol. 47, No. 1 (2019) 
$1 \mathrm{ng} \mu \mathrm{l}^{-1}$ prior to testing and each isolate was tested in duplicate under the same PCR conditions as described before.

Testing the conventional PCR analytical sensitivity and the limit of detection (LOD):

Sensitivity of the PCR assay was assessed with the gDNA of the positive control of the reference isolate (LSVM 302) diluted in water. Ten-fold serial dilutions

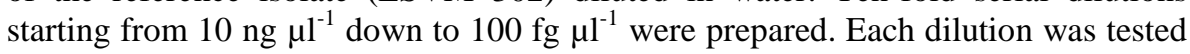
by PCR in 2 replicates. The least concentration that generated positive results in all replicates was designated as the limit of detection (LOD) of the method.

Testing the conventional PCR repeatability and reproducibility:

Two concentrations, i.e. the detected LOD and 0.1 of the LOD were tested in 10 replicates for each. This test was carried out by two different operators in different days as two separate experiments. The generated results were used to calculate the percentage of agreement among the different replicates as repeatability. While the percentage of agreement among replicates of the two different experiments (different operator and date) was calculated to express reproducibility.

Field validation of FOA detection protocol on date palm samples:

Following the full validation of the conventional PCR diagnostic protocol of FOA, it was further implemented on samples collected from different locations of growing date palm in Egypt, in addition to samples presenting the date palm consignments imported from other countries.

Testing date palm samples from Egyptian fields:

Samples collection and isolation:

A total of 14 samples were collected from three different date palm growing areas in Egypt; Kerdasa, Badrshin and Giza counties (ARC farm) during the year 2019 to be tested for the presence of FOA. Samples were collected from trees and offshoots showing symptoms of general wilting, yellowing, chlorosis, and tree mortality.

Isolation from the collected samples was carried out by cutting up the vascular tissues of leaflet, rachis and roots into small segments. The plant segments were then surface sterilized in 5\% of sodium hypochlorite for 2-3 minutes then rinsed in sterile distilled water and dried between layers of sterilized filter papers. Five plant segments were transferred to sterilized Petri dishes containing potato dextrose agar (PDA) and two plates were used for each sample. All the plates were incubated at $25 \pm 2{ }^{\circ}$ Cfor five days with daily checking for fungal growth emergence. The generated mycelia were transferred to new plates and a single spore technique was carried out in order to purify the obtained colonies (Dhingra and Sinclair, 1985). 
Fusarium colonies were segregated based on morphological characteristics for further molecular detection of FOA (Leslie and Summerell, 2006).

Molecular detection of FOA:

Fusarium strains isolated from date palm samples were tested by the conventional PCR method of Fernandez et al. (1998) using the specific primer pair of TL3/FOA28 as described before.

Testing date palm samples imported from different countries:

A total of 43 date palm plantlets sampled from consignments imported from 5 different countries during the year 2019 for plantation purpose in Egypt were checked for the absence of $F$. oxysporum f. sp. Albedinis before issuing entry permission. Isolation from the date palm tissues, identification of the isolated fungi and performing conventional PCR using the specific primer pairTL3/FOA28 for FOA detection, were carried out as described before.

\section{Results}

Validation of the molecular detection method of F. oxysporum f.sp. albedinis:

Preliminary check of the conventional PCR assay:

A conventional PCR method was validated for detection of $F$. oxysporum f.sp. albedinis. A preliminary check on the method was carried out to set up the work conditions during this investigation. Results show that the primer pair TL3/FOA28 was able to amplify a fragment of 400bp with the tested DNA of the reference isolate (LSVM 302), while no band was obtained from the non-target isolate of $F$. oxysporum f.sp. lycopersici (PQPL-95-5) (Fig.,1) which indicated that no amplification was occurred for this isolate. Hence, the adopted method did not require any optimization neither for PCR reaction mixture nor for the PCR cycling program.

Specificity and sensitivity of the conventional PCR assay:

The specificity of the PCR assay was carried out for the target FOA (LSVM 302) in addition to 11 non-target Fusarium isolates. The target FOA (LSVM 302) yielded positive response, while the other tested strains gave a negative result. Hence, no cross reaction was observed with any of the non-target species tested in this assay (Table, 1).

The sensitivity of the PCR method was assessed with 6 different concentrations of gDNA of FOA (LSVM 302). The highest three concentrations generated positive results in at least one replicate were $10 \mathrm{ng}^{-1} \mathrm{l}^{-1}, 1 \mathrm{ng} \mathrm{I}^{-1}$ and $100 \mathrm{pg}^{-1} \mathrm{l}^{-1}$. However,

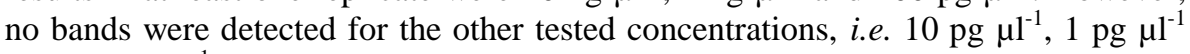
and $100 \mathrm{fg} \mu \mathrm{l}^{-1}$ (Fig., 2).

Egypt. J. Phytopathol., Vol. 47, No. 1 (2019) 
Table (1): List of fungal isolates used in this study for testing the specificity of conventional PCR

\begin{tabular}{|c|c|c|c|c|c|c|}
\hline Fungal species & Isolate $^{*}$ & Host & origin & Year & $\begin{array}{l}\text { ITS1/ } \\
\text { ITS4* } \\
*\end{array}$ & $\begin{array}{c}\text { Detection } \\
\text { by TL3/ } \\
\text { FOA28 } \\
\text { primer } \\
\text { pair }\end{array}$ \\
\hline $\begin{array}{l}F \text {. oxysporum f.sp. } \\
\text { albedinis }\end{array}$ & LSVM 302 & $\begin{array}{l}\text { Phoenix } \\
\text { dactylifera }\end{array}$ & Morocco & 2001 & + & + \\
\hline F. oxysporum & PQPL-101 & $\begin{array}{c}\text { Phoenix } \\
\text { dactylifera }\end{array}$ & $\begin{array}{l}\text { Saudi } \\
\text { Arabia }\end{array}$ & 2018 & + & - \\
\hline F. oxysporum & PQPL-110 & $\begin{array}{c}\text { Phoenix } \\
\text { dactylifera }\end{array}$ & $\begin{array}{l}\text { United } \\
\text { Arab } \\
\text { Emirates }\end{array}$ & 2018 & + & - \\
\hline F. solani & PQPL-111 & $\begin{array}{c}\text { Phoenix } \\
\text { dactylifera }\end{array}$ & $\begin{array}{l}\text { Saudi } \\
\text { Arabia }\end{array}$ & 2018 & + & - \\
\hline Fusarium species & PQPL-112 & $\begin{array}{c}\text { Phoenix } \\
\text { dactylifera }\end{array}$ & England & 2018 & + & - \\
\hline Fusarium species & PQPL-113 & $\begin{array}{c}\text { Phoenix } \\
\text { dactylifera }\end{array}$ & France & 2018 & + & - \\
\hline $\begin{array}{l}F . \text { oxysporum f.sp. } \\
\text { niveum }\end{array}$ & PQPL-51 & $\begin{array}{l}\text { Citrullus } \\
\text { lanatus }\end{array}$ & Egypt & 2016 & + & - \\
\hline $\begin{array}{l}F . \text { oxysporum f.sp. } \\
\text { lycopersici }\end{array}$ & PQPL-95-5 & $\begin{array}{c}\text { Solanum } \\
\text { lycopersicum }\end{array}$ & Egypt & 2018 & + & - \\
\hline $\begin{array}{l}\text { F. oxysporum f.sp. } \\
\text { lycopersici }\end{array}$ & PQPL-95-7 & $\begin{array}{c}\text { Solanum } \\
\text { lycopersicum }\end{array}$ & Egypt & 2018 & + & - \\
\hline $\begin{array}{l}\text { F. oxysporum f.sp. } \\
\text { lycopersici }\end{array}$ & PQPL-95-8 & $\begin{array}{c}\text { Solanum } \\
\text { lycopersicum }\end{array}$ & Egypt & 2018 & + & - \\
\hline $\begin{array}{l}F . \text { oxysporum f.sp. } \\
\text { capsici }\end{array}$ & PQPL-80 & $\begin{array}{l}\text { Capsicum } \\
\text { аппиит }\end{array}$ & Egypt & 2017 & + & - \\
\hline $\begin{array}{l}F . \text { oxysporum f.sp. } \\
\text { capsici }\end{array}$ & PQPL-81 & $\begin{array}{l}\text { Capsicum } \\
\text { annuиm }\end{array}$ & Egypt & 2017 & + & - \\
\hline
\end{tabular}

* The isolate LSVM302 was obtained from ANSES collection and PQPL refers to the isolates obtained from the Mycol. Res. and Dis. Survey Dept.

** DNA extracts were checked for amplifiability using ITS1/ITS4 primer pair prior testing the specificity to ensure proper amplification conditions and excluding the possibility of reaction failure leading to false-negative results

$+:$ indicate positive result

-: indicate negative result 


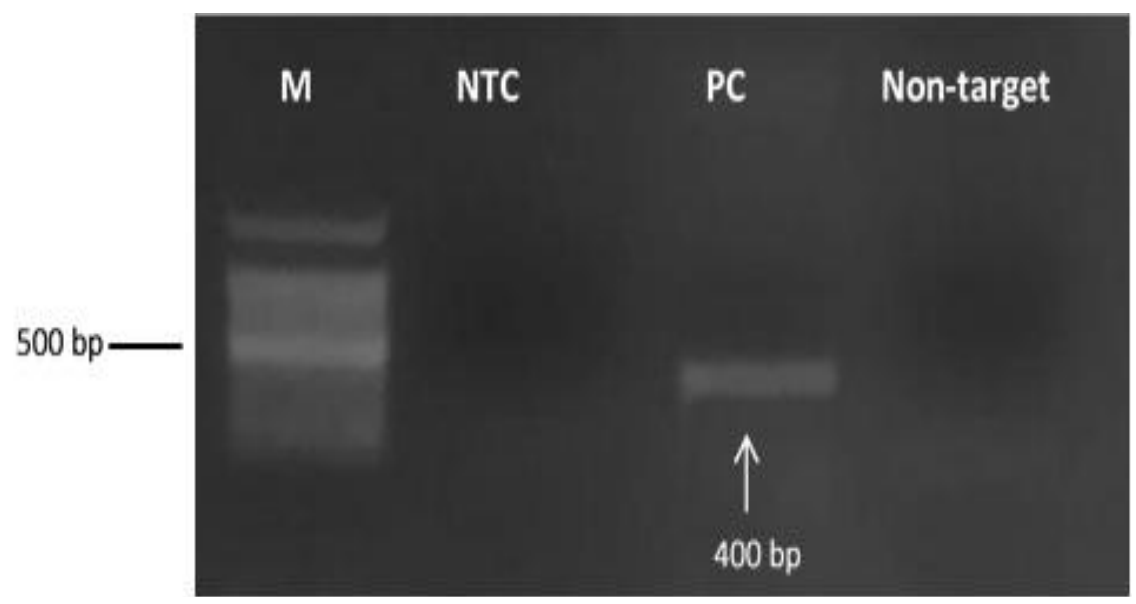

Fig.1 Agarose gel electrophoresis of amplified PCR products obtained by TL3/ FOA28 primer pair. Lane: M, 100bp ladder; NTC is negative control from $\mathrm{H}_{2} \mathrm{O}$; PC, positive control of PCR product from the reference $\mathrm{FOA}$ isolate (LSVM 302) with expected size of 400bp, and Non-target PCR product from F. oxysporum f.sp. lycopersici (PQPL-95-5) isolate.

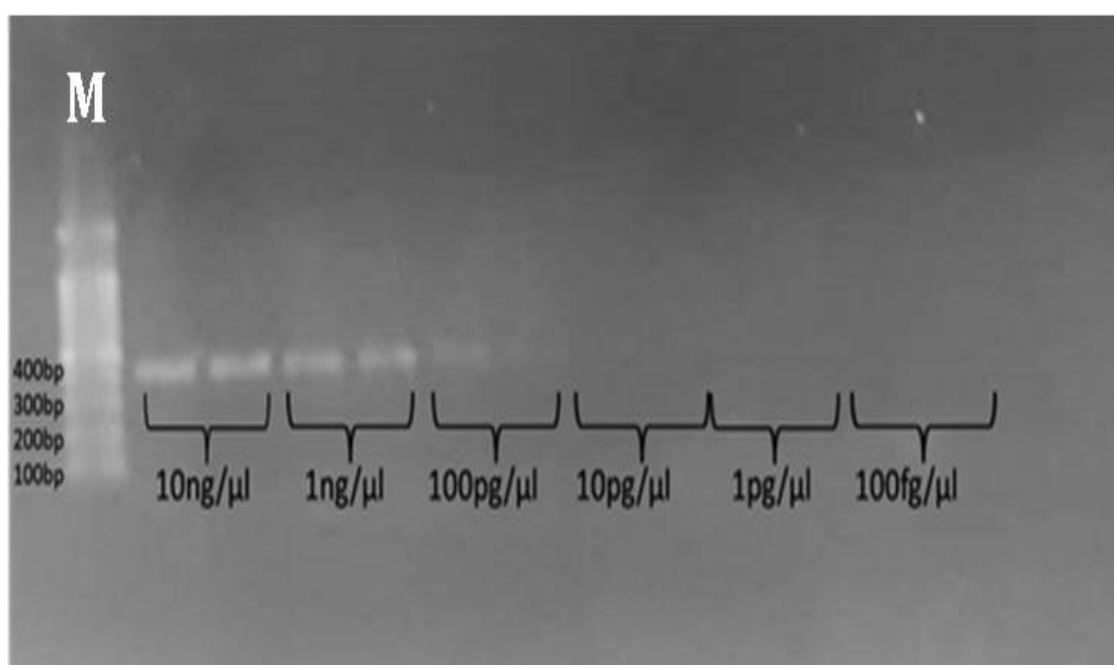

Fig. 2 Agarose gel electrophoresis of amplified PCR products obtained by the primer pair TL3 / FOA28 for testing the sensitivity using six different

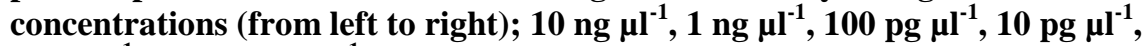
$1 \mathrm{pg} \mu \mathrm{l}^{-1}$ and $100 \mathrm{fg}_{\mu l^{-1}}$. Two replicates were loaded for each concentration. Lane $M$ is a $100 \mathrm{bp}$ ladder.

Egypt. J. Phytopathol., Vol. 47, No. 1 (2019) 
Repeatability and reproducibility of the assay

The intra-assay repeatability showed that only the concentration of $1 \mathrm{ng}_{\mu \mathrm{l}^{-1}}$ (LOD)was able to generate clear positive bands in repeatable detectable manner

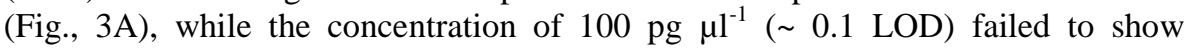
repeatable results and yielded negative results (data unpublished). Assessment of inter-assay reproducibility showed the same results both with $1 \mathrm{ng} \mu \mathrm{l}^{-1}$ (LOD)

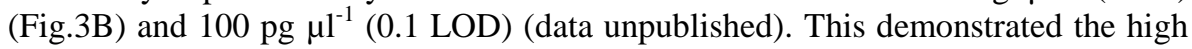
consistency among results to detect FOA using the conventional PCR method even applied by different operators. The level of agreement is $90 \%$ at LOD $(1 \mathrm{ng} / \mu \mathrm{l})$, while at concentration lower than LOD, it was not possible to generate consistent positive results.
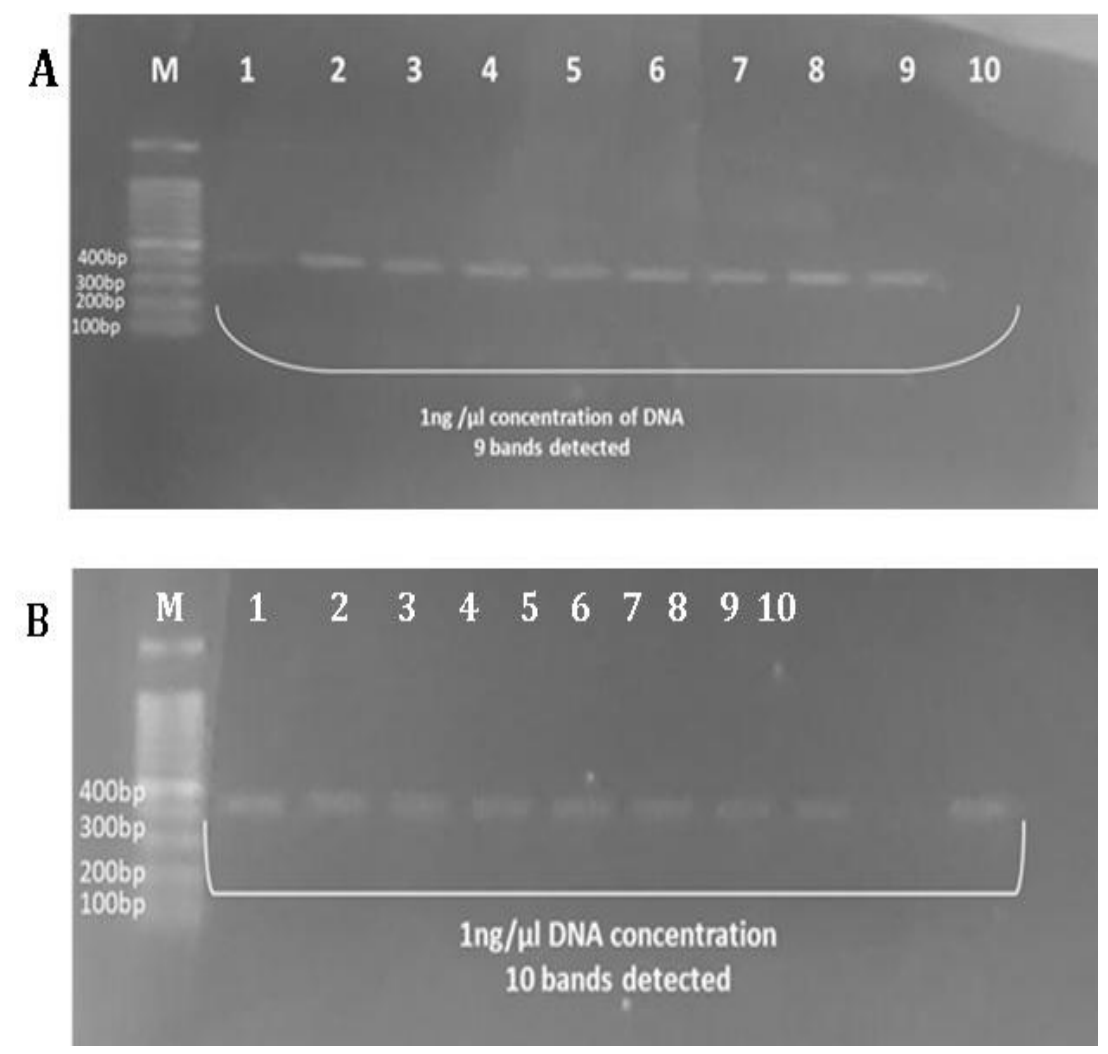

Fig. 3 Agarose gel electrophoresis of amplified PCR products obtained by the primer pair TL3 / FOA28 for testing the repeatability (A) and reproducibility (B) using 10 replicates of $\mathrm{LOD}$ concentration $\left(1 \mathrm{ng} \mathrm{\mu l}^{-1}\right)$. Lane $M$ is a $100 \mathrm{bp}$ ladder. The reproducibility was performed by different operator and in different dates. 
Testing date palm samples from Egyptian fields:

Isolation and morphological identification

Isolation from the collected samples resulted in 126 fungal colonies of Fusarium spp. that were recovered from the leaflets, rachis, and roots of the used samples. Based on the morphological characteristics, the majority of these colonies were distinguished as Fusarium oxysporum.

\section{Molecular detection of FOA}

All the isolated Fusarium strains were further tested by PCR for detecting FOA using the specific primer pair TL3/FOA28. All the tested isolates gave negative result. Therefore, no F. oxysporum f.sp. albedinis was detected in the tested date palm samples.

Testing date palm samples imported from different countries.

The direct isolation from the imported date palm samples revealed the presence of various Fusarium spp. colonies. Based on the morphological characters, suspected colonies to be $F$. oxysporum were further tested by PCR using specific primer pair TL3/FOA28. PCR results were negative for all the tested samples. Therefore, no interception cases for FOA were reported for any of the countries of origin (Table, 2). It was noticeable that the other Fusarium species (F. solani, F. semitectum, $F$. subglutinans and some other imperfect fungi (Trichoderma sp., Alternaria sp., and Geotrichum sp.) were always associated with roots of the tested date palm tissues presenting imported samples.

Table (2): Testing imported date palm samples for the presence of FOA

\begin{tabular}{lcc}
\hline Country of origin & No. of samples & $\begin{array}{c}\text { Detections of FOA by } \\
\text { PCR }\end{array}$ \\
\hline Saudi Arabia & 16 & Negative \\
United Arab Emirates & 20 & Negative \\
England & 4 & Negative \\
France & 2 & Negative \\
USA & 1 & Negative \\
\hline
\end{tabular}

\section{Discussion}

Date palm industry is one of the most promising sectors for investment in Egyptian agriculture, which could assist in achieving strong economic growth, boost exports, and creating new jobs. For that reason, Egypt is currently working on establishing the largest date palm plantations in the world that aims to plant about 2.5 million palm trees to produce top-quality dates. Most of the planting materials will be imported from abroad and this flow of traded plants might impose potential risk of FOA dispersal into the country. In Egypt, the responsibility for phytosanitary 
measures against the introduction of quarantine plant pathogens is shared by Central Administration of Plant Quarantine (CAPQ) and Plant Pathol. Res. Inst. (PPathRI). The availability of a rapid and reliable diagnostic tool for detection of FOA will enable the CAPQ to test date palm tissues for the presence of such a devastating quarantine pathogen. In this study, we aimed to determine the reliability of a detection method for specific and accurate differentiation of the real casual pathogen of Bayoud either from other pathogenic $F$. oxysporum formae specialis that cause diseases on date palm or from any other species that could be encountered in date palm tissue. Our utmost goal was to validate and further implement this tool to prevent the introduction of FOA into Egypt. Although F. oxysporum f.sp. albedinis is so far not reported in Egypt and is regulated as A1 in Egyptian quarantine list, EPPO has stated that in the year 1993, infected date palm material exported from Egypt has been intercepted in Spain (EPPO database; https:/gd.eppo.int/reporting/article-5037). To respond for such a claim and to confirm the presence or absence of the disease in Egypt, both comprehensive survey and a reliable diagnostic protocol are needed. Diagnosis of Bayoud based on symptoms is challenging and could be confused with false Bayoud or other symptoms induced by different fungal pathogens (Ammar and El-Naggar, 2011). Morphological characteristics are inadequate for differentiation between FOA and other Fusarium formae specialis (Freeman and Maymon, 2000). In most cases, pathogenicity test is required to verify the identity of FOA in date palm. However, this method is still considered unreliable for confirming the casual pathogens since another formae specialis, i.e. F. oxysporum f.sp. canariensis, was also reported to be pathogenic on date palm seedlings (Feather et al. 1989). Furthermore, the pathogenicity test is not suitable for rapid decision as it is time consuming requiring 3 to 6 months for symptoms appearing. A RAPD-PCR technique was developed by Freeman and Maymon (2000) for FOA detection, but the method demonstrated to be less accurate as similar banding patterns were observed with gDNA of FOA and gDNA of other Fusarium species.

Therefore, the core element for developing an accurate PCR assay is the choice of well-designed primers that achieve the balance between high sensitivity and specificity. Fernandez et al. (1998) designed the primer pair of TL3/FOA28 based on the regions flanking the inserted transposable element Fot 1 at specific loci within the genome of $F$. oxysporum f.sp. albedinis. The TL3/FOA28 primer pair has proved to amplify a fragment of $400 \mathrm{bp}$ that found only in $F$. oxysporum f.sp. albedinis isolates when tested with 286 isolates of FOA, 17 forma specialis, non-pathogenic $F$. oxysporum isolates from palm grove soils, and 8 other Fusarium species (Fernandez et al., 1998).

The current study aimed to validate the PCR method developed by Fernandez et al. (1998) for the detection of FOA under the Egyptian laboratory conditions. The results showed that the assay is specific, inclusive and sensitive for detecting FOA with a concentration as little as $1 \mathrm{ng} \mu \mathrm{l}^{-1}$ of $F$. oxysporum f.sp. albedinisg, DNA. The Egypt. J. Phytopathol., Vol. 47, No. 1 (2019) 
performance criteria of repeatability and reproducibility were acceptable, and all the validation process is in line with the requirements of EPPO standard PM 7/98 (EPPO, 2010). A series of quality assurance controls have been implemented which provide full confidence of the generated results. Based on these data and in compliance with ISO ISO/IEC. (17025:2017) requirements, our laboratory PQPLPPathRI was recently accredited by the Egyptian Accreditation Council (EGAC) for implementing this detection protocol. The validated PCR assay proved to be significantly more efficient and rapid than performing the pathogenicity test that usually is essentially required to confirm the formae specialis of $F$. oxysporum. Thus, the PCR assay is suitable and fits the intent of use for phytosanitary purposes. The applicability of the protocol for testing natural date palm tissues was further demonstrated by analysing 14 different samples collected from local date palm fields. All the identified $F$. oxysporum isolates were negative for Bayoud by PCR assay. Although the number of samples analysed in our study was quite limited, but our results could be used to reject any claims of wide distribution of $F$. oxysporum f.sp. albedinis in Egypt. However, a national detection survey program with robust statically data and based on the ISPM No. 6, "Guidelines for surveillance" (FAO, 1997) and ISPM no. 8, "Determination of Pest Status in an Area" (FAO, 1998) is still of crucial importance to confirm our hypothesis of Fusarium-free status of Egypt .

Fusarium spp. are one of the important phytopathogenic fungi that have been associated with roots, fronds and trucks of date palm trees (Alwahshi et al. 2019). Fusarium oxysporum, and $F$. moniliforme were isolated from date palm plants showing root rot symptoms (Arafat et al., 2012). In Saudi Arabia, from 70 Fusarium isolates collected from infected fronds and roots of date palm trees, $70 \%$ were identified as $F$. proliferatum that were recovered from six regions while $13 \%$ were identified as $F$. solani. F. brachygibbosum, F. oxysporum, and $F$. verticillioides were also recovered while $F$. oxysporum f.sp. albedinis was absent (Abdalla et al., 2000 and Saleh et al., 2017). In Iran, $F$. solani was associated with the yellow death on date palm (Mansoori and Kord, 2006). F. oxysporum, F. proliferatum and F. solani were recently reported as causal pathogens of date palm sudden decline syndrome in the United Arab Emirates while the status of $F$. oxysporum f.sp. albedinis is still confirmed to be absent (Alwahshi et al., 2019).

The reliability of the conventional PCR assay was also further validated by testing date palm plant materials imported from 5 countries, i.e. Saudi Arabia, United Arab Emirates, England, France, and USA, from different date palm varieties such as Majdul and Barhi, (data not shown). Although all the imported varieties were considered to be susceptible, we could not detect any presence of $F$. oxysporum f.sp. albedinis in all the 43 tested samples. This could be explained as these countries of origin were already reported to be free from FOA (EPPO Global Database). However, CAPQ and PPathRI are committed to enforce strict phytosanitary measures to prevent the introduction of FOA by testing all the Egypt. J. Phytopathol., Vol. 47, No. 1 (2019) 
imported plant materials. It is also worth mentioning that some of these countries often grow some incidental hosts of FOA such as Lawsonia inermis (henna), Medicago sativa (lucerne) and Trifolium spp. (clovers) which were reported as being symptomless carriers of F. oxysporum f.sp. albedinis (Djerbi et al., 1985).

Another relevant pathway for the entry of FOA into Egypt is the soil and growing media attached to plants that are not necessarily host plant of FOA and originating in Algeria and Morocco. In this context, during 2018 and 2019 three soil samples attached to olive seedlings imported from Morocco have been screened for FOA prior to entry (data unpublished).

\section{Conclusions}

Fusarium oxysporum f.sp. albedinis (FOA) is the most serious fungus threatening date palm. In this study, we demonstrated that the conventional PCR detection protocol proposed by Fernández et al., (1998) is reliable and accurate for detecting FOA. The results of our research will be of a great help for CAPQ to perform national survey programs for verification the status of FOA in Egypt. The method is currently being implemented by the Plant Pathology Research Institute for testing the imported date palm materials. Adoption of such detection methods of quarantine pathogens by the domestic diagnostic laboratories proofs that Egyptian phytosanitary procedures are in harmonization with the international standards.

\section{Acknow ledgment}

This research was funded by the Science and Technology Development Fund (STDF), Egypt (grant No. 15235- Basic \& Applied). All the experiments were conducted at the Plant Quarantine Pathogens Laboratory (PQPL), Mycology Res. and Dis Survey, Plant Pathol. Res. Inst., Agricultural Research Center, Giza, Egypt.

\section{References}

Abdalla, M.Y.; Al-Rokibah, A.; Moretti, A. and Mulè, G. 2000. Pathogenicity of toxigenic Fusarium proliferatum from date palm in Saudi Arabia. Plant disease, 84:321-324.

Alwahshi, K.J.; Saeed, E.E.; Sham, A.; Alblooshi, A.A.; Alblooshi, M.M.; ElTarabily, K.A. and AbuQamar, S.F. 2019. Molecular identification and disease management of date palm sudden decline syndrome in the United Arab Emirates. Int. J. Mol. Sci., 20(4):923.

Ammar, M.I. and El-Naggar, M.A. 2011. Date palm (Phoenix dactylifera L.) fungal diseases in Najran, Saudi Arabia. Int. J. Plant Pathol., 2:126-135.

Arafat, K.H.; Mohamed, A.M. and Elsharabasy, S. 2012. Biological control of date palm root rots disease using Egyptian Isolates of Streptomycetes. Res. J. Agric. Biol. Sci., 8:224-230. 
Benzohra, I.E., Megateli, M.; Elayachi, B.A.; Zekraoui, M.; Djillali, K.; Bouafia, A.; Benouis, S.; Benaziza, A. and Rekis, A. 2017. Integrated management of Bayoud disease on date palm (Phoenix dactylifera $\mathrm{L}$.) caused by Fusarium oxysporum $\mathrm{f}$. sp. albedinis in Algeria. J. Algerien des Regions Arides, 14: 93-100.

Djerbi, M. 1982. Bayoud disease in North Africa, history, distribution, diagnosis and control. Date Palm J., 1:153-197.

Djerbi, M. 1983. Diseases of the date palm (Phoenix dactylifera). The Food and Agriculture Organization (FAO), Baghdad, Iraq. 106 pp.

Djerbi, M.; El Ghorfi, A. and El-Idrissi A.M.A. 1985. Etude du comportement du henne Lawsoniainermiset de la luzerne Medicago sativa et quelques especes de palmacees vis-a-vis du Fusarium oxysporum f.sp. albedinis, agent causal du bayoud. Annales de L'Institut National de la Recherche Agronomique de Tunisie, 58: 1-11.

Dhingra, O.D. and Sinclair, J.B. 1985. Basic Plant Pathology Methods. CRC Press, Florida, 355pp.

EPPO. 2010. PM 7/98 (1): Specific requirements for laboratories preparing accreditation for a plant pest diagnostic activity. EPPO Bull., 40: 5-22.

FAOSTAT, 2018. FAOSTAT statistical database. Available online: www.fao.org/faostat/. [Rome]: FAO.

FAO, 1997. ISPM No 6. Guidelines for Surveillance. International Standards for Phytosanitary Measures, Publication No.6. Secretariat of the International Plant Protection. FAO Publication Division, Rome, Italy.

FAO, 1998. ISPM No.8. Determination of Pest Status in an Area. International Standards for Phytosanitary Measures, Publication No 8. Secretariat of the International Plant Protection. FAO Publication Division, Rome, Italy.

Feather, T.V.; Howard D.Ohr.; and Carpenter, J.B. 1989. The occurrence of Fusarium oxysporum on Phoenix canariensis, a potential danger to date production in California. Plant Dis., 73: 78.

Fernandez, D.; Ouinten, M.; Tantaoui, A.; Geiger, J.P.; Daboussi, M.J.; and Langin, T. 1998. Fot 1 insertions in the Fusarium oxysporum f. sp. albedinis genome provide diagnostic PCR targets for detection of the date palm pathogen. Appl. Environ. Microbiol., 64: 633-636.

Fernandez, M.; Lourd, M.; Ouinten, M.; Tantaoui, A. and Geiger, J.P. 1995. Le Bayoud du palmier dattier, unemaladie qui menace la phoeniciculture. Phytoma, 469: 36-39.

Egypt. J. Phytopathol., Vol. 47, No. 1 (2019) 
Freeman, S. and Maymon, M. 2000. Reliable detection of the fungal pathogen Fusarium oxysporum f.sp. albedinis, causal agent of bayoud disease of date palm, using molecular techniques. Phytoparasitica, 28: 341-348.

ISO/IEC. 17025, 2017. General requirements for the competence of testing and calibration laboratories. International Organization for Standardization (ISO).

Leslie, J.F. and Summerell, B.A. 2006. The Fusarium Laboratory Manual. John Wiley \& Sons, New York, NY. 388 pp.

Mansoori, B. and Kord, M.H. 2006. Yellow Death: A disease of date palm in Iran caused by Fusarium solani. J. of Phytopathology, 154: 125-127.

Saleh, A.A.; Sharafaddin, A.H.; El-Komy, M.H.; Ibrahim; Y.E.; Hamad, Y. K. and Molan, Y.Y. 2017. Fusarium species associated with date palm in Saudi Arabia. Eur. J. Plant Pathol., 148: 367-377.

Sedra, M. 2015. Date palm status and perspective in Mauritania. In: Al-Khayri, J.M.; Jain, S.M.; Johnson, D.V. (eds). Date Palm Genetic Resources and Utilization: Volume 1. Springer, Dordrecht. Pages 325-368.

Toutain, G. and Louvet, J. 1974. Luttecontre le bayoud. IV. Orientations de la lutte au Maroc. Al-Awamia 53: 114-162.

White, T.J.; Bruns, T.; Lee, S. and Taylor, J. 1990. Amplification and direct sequencing of fungal ribosomal RNA genes for phylogenetics. In: PCR Protocols, a Guide to Methods and Applications, 315-322.

Corresponding author: Ahmed, $Y$

E-mail: yosra242@yahoo.com

(Received 31/03/2019;

in revised form 21/04/2019) 


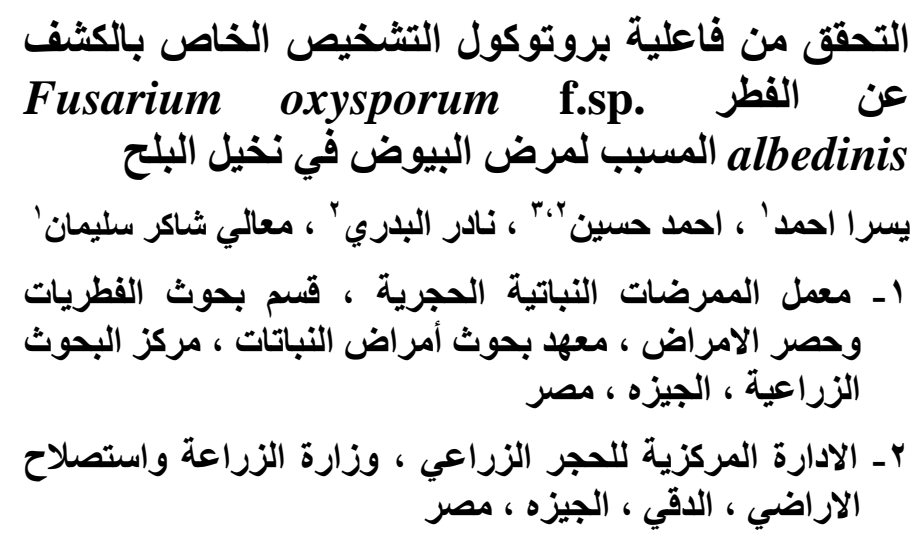

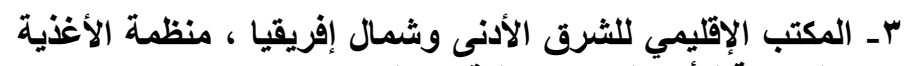

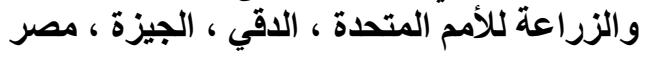

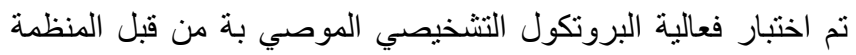

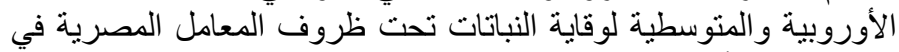

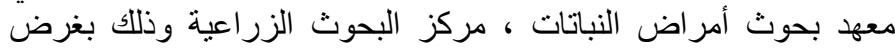

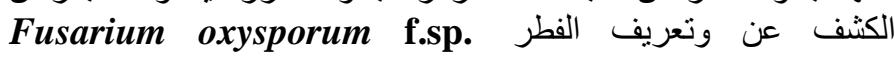
albedinis

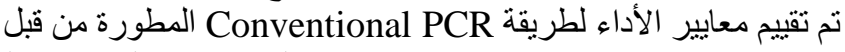

من حيث حساسية وتخصصية وتكرارية

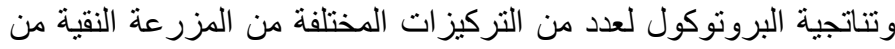

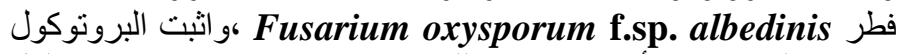

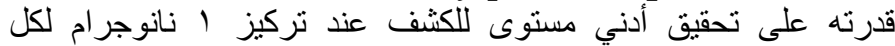
ميكرولتر، وكذلك تحقيق تخصصية كاملة ووصلت تكرارية النتائج إلى الى

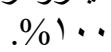

بالإضافة إلى ذلك فقد تم اختبار فاعلية البروتوكول وتطبيقه في اختبار

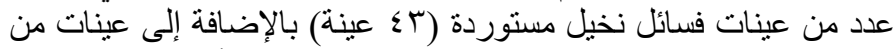

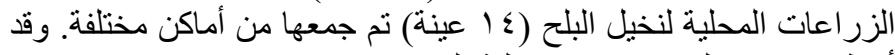

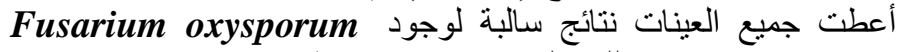
f.sp. albedinis بكثافه عالية في معظم العينات. 